\title{
本論文は複数のレフェリーの憲査を受けたものです。 \\ Foreign Capital: Productivity and Spillover Effect in Hungary
}

\author{
Graduate School of International Cultural Studies, Tohoku University \\ Valéria Szekeres
}

\section{Introduction}

Importance of foreign firms in Hungary is reflected in the fact that after only seven years from the beginning of the inflows of considerable amounts of foreign direct investment, the foreign share in nominal capital in the economy reached $35 \%$ by 1997 . Thus, it might be important to evaluate the role that foreign enterprises play in the economic growth by estimating their productivity relative to that of domestic companies.

Eclectic theory of Dunning suggests that multinationals have ownership-specific advantages that allow them to produce and successfully compete with domestic producers in a host country, which enjoy certain advantages vis-a-vis them, as far as the familiarity with the local legal or business culture is concerned. These firm-specific advantages mainly include physical as well as intangible assets embodied in managerial capabilities, marketing or engineering. Advantages also arise from common governance, which are related partly to economies of scale on firm level, partly to market power, technology accumulated worldwide and other attributes caused by multinationality. Operating in a number of countries stimulates the development of specific competencies, which are not available to purely national firms. ${ }^{(1)}$

As a criterion for comparison between efficiency of foreign and domestic firms, total factor productivity (TFP) is often chosen. Most empirical studies show positive, but not always statistically significant differences in productivity between foreign and domestic enterprises. Moreover, after controlling for such factors as size or capital intensity, the analyses have more mixed results with findings often showing no difference. ${ }^{(2)}$ Here, better productivity indicators are revealed for foreign firms by the Cobb-Douglas production function, although we cannot control for influencing factors.

It may be reasonable to expect that foreign firms, as manufacturers of innovated products and possessors of international production experience positively affect the economic performance of domestic enterprises. Such external effects are called spillovers in the literature. One type of them is identified through linkages with suppliers of foreign firms, which may take the form of information linkages, technical assistance on innovation, product design or quality control, provision of used machinery, help in obtaining equipment or materials at competitive prices, and financial assistance. Other widely acknowledged impact of multinationals is that their existence increases competition in the industry they operate, thus, inspiring rival domestic firms to better performance. Another source of gains from spillover impacts of foreign firms includes training of labor and management, investment in human capital which may later become available to host firms, if they choose them to work for. ${ }^{(3)}$

Majority of the field studies carried out on the topic found that in industries where foreign direct investment is concentrated local competitors were indeed forced to upgrade their own performance. Econometric analyses showed a positive relationship between the presence of foreign-owned firms and the labor productivity in particular industries. They also emphasized that the main impact of inward investment was the result of larger competition rather than of transfer of technology. ${ }^{(4)}$ In the case of Hungary, 
although the competitive positions of domestic firms are weak and a large volume of foreign capital has only been recently present, Hunya (1997) reported that restructuring generally featured at firms of all types of ownership. Domestic enterprises may be induced to take measures towards increasing their productivity either by getting rid of overemployment or by making efforts to introduce more advanced operation methods, of which foreign competitors may give a demonstration. The impact of foreign firms on their suppliers can also be considered as an important form of spillover.

In line with the econometric method applied by Blomstrom and Persson (1983) for Mexico, this paper attempts to reveal intra-industry externalities of foreign firms by concentrating on only one indicator of the possible spillover impacts that is the labor productivity. Similarly to the study mentioned we assume that there is a favorable spillover effect of foreign investment if a positive relation can be revealed between the labor productivity of domestic firms and the presence of foreign firms in various sectors. In lack of further data, we are not able to estimate and exclude the impact of other factors influencing the productivity. The result of the analysis here shows that there is some spillover impact of the foreign presence.

The structure of this paper is as follows. Section 2 presents analysis results on some countries other than Hungary. In section 3, the sources and description of data are given. Section 4 includes the Cobb-Douglas production function model and its estimation. Section 5 gives an analysis of the spillover effect of foreign firms. Finally, section 6 concludes.

\section{Results of previous papers}

The few analyses in the topic came generally to the conclusion that foreign firms perform better in respect of total factor productivity. Sun (1998) estimated the Cobb-Douglas production function for data of state-owned and foreign firms in Chinese industries in 1995. Using in a regression equation the figures of value added, net value of fixed capital used directly in production, and the number of employees on a yearly average, he found that the level of technology was higher at foreign enterprises. Agarwal (1979) calculated the total factor productivity in the Indian industries by the ratio of value added to the sum of capital and labor, given by the product of capital and opportunity cost, and labor and average wage rate, respectively. For the manufacturing average, TFP of foreign firms exceeded that of domestic ones by $55 \%$.

Tyler (1978) showed for Brazilian manufacturing data in 1971, that foreign firms as a whole exhibited greater technical efficiency than domestic firms only in the case when their output elasticity were constrained to be the same. When dummies were used in the regression equation to indicate the differences of the respective output elasticity for foreign firms in relation to domestic firms, the intercept dummy for foreign firms was no longer positive, but negative. At the same time, noteworthy differences appeared in the output elasticity of factors of foreign and domestic firms in the Cobb-Douglas production function, indicating that greater returns to scale for foreign firms was previously interpreted as their greater technical efficiency.

Blomstrom and Persson (1983) estimated the effect of foreign capital on labor productivity of domestic firms for the 1970 data of 215 manufacturing industries in Mexico. After controlling for capital intensity, scale economies, quality of labor, concentration index and effective average workdays within industries, the study found support for the spillover efficiency. 


\section{Data and definition of firms}

Data are derived from the aggregate balance sheet data of all enterprises in Hungary that were obliged to report to the Tax and Financial Audit Office in the period between 1994 and 1997. For the purpose of this paper the Department of Taxation of the Office conceded the use of the aggregate data in their yearly reports, which are, however, confidential and not allowed to be published. Figures used in the analysis include the gross value added, number of employees and equity, classified into 25 sectors.

It may be conceivable to assume that productivity of foreign firms differ from each other according to the size of foreign share. Thus, we discriminate between three types of foreign firms. Firms at which the foreign share in nominal capital is below $25 \%$ but more than $0 \%$ are also regarded foreign enterprises, although this is unusual in the economic literature. Hunya (1997) notes that even in firms with minor foreign share the foreign partner is in a position to crucially affect management decisions, if the majority owner is a public one. In this case, minority foreign-owned companies might improve management and efficiency of production, as if they were majority foreign-owned. Thus, it seems appropriate to consider foreign investment of a size even below $25 \%$ as direct and not portfolio investment. Constraints of data also point to the need of regarding firms foreign, if the foreign share is between $0 \%$ and $25 \%$, since we rely on the ownership categories provided by the Tax and Financial Audit Office. FEs1 will include those firms at which the foreign share in nominal capital is below $25 \%$, but more than $0 \%$. FEs2 will indicate enterprises, where foreign share is between $25 \%$ and $50 \%$. FEs3 will refer to firms, in which foreign share of nominal capital is above 50\%. Domestic enterprises (DEs) will include state-owned companies and private enterprises owned entirely by Hungarian nationals.

\section{Production function approach}

Total factor productivity assesses the economic and technical efficiency with which resources are converted into products at firms. It is usually expressed in terms of output per unit of total factor inputs in a function of quantities or prices of output and inputs, scale elasticity and output and input elasticity. Due to the necessary simplification of production and markets, TFP measures not only the 'level of technology', but also the issues influencing production inside and outside the firm. By measuring only the inputs and output, the sole possibility is to treat engineering knowledge, plant organization or disruptions in market affecting production process, as a whole. ${ }^{(5)}$ The Cobb-Douglas production function is applied in the analyses and specified as

$$
\mathrm{Q}=A L^{\mathrm{a}} \mathrm{K}^{\mathrm{b}}, \quad(\mathrm{A}>0, \mathrm{a}>0, \mathrm{~b}>0) .
$$

$\mathrm{Q}, \mathrm{L}$ and $\mathrm{K}$ denote output, labor and capital input respectively. $\mathrm{A}$ is a parameter representing the level of technology at time t. Parameters a and b are the output elasticity with regard to labor and capital respectively.

The model is assumed linearly homogenous $(a+b=1)$; in that case it has constant returns to scale, which means that if both inputs are multiplied by any positive constant, output changes by the same factor. If the Cobb-Douglas production function is not linearly homogeneous and $a+b>1$, the function exhibits increasing returns to scale. While in the case of $a+b<1$, it has decreasing returns to scale.

Regression equation of the Cobb-Douglas function is written as follows

$$
\ln \mathrm{Q}=\alpha+\mathrm{a} \ln \mathrm{L}+\mathrm{b} \ln \mathrm{K}, \quad(\alpha(\text { constant })=\ln \mathrm{A}) .
$$


Models in the next section analyzing productivity at foreign and domestic firms in Hungary from various aspects take this equation as a base. The method of ordinary least squares is chosen to calculate regression.

\subsection{Models and estimation results of TFP}

Models are estimated with figures for the whole economy given by 25 sectors between 1994 and 1997 . Since logarithm cannot be taken if figures are zero or negative, the database of each model is adequately adjusted to exclude those sectors, in which some of the figures cannot be interpreted. As with the results of TFP analyses for other countries, foreign firms are found more productive also in Hungary.

The first model is a cross-section model, analyzing the difference in the level of TFP at firms for every year between 1994 and 1997.

$$
\operatorname{lnVA}=\alpha+\beta_{1} \operatorname{lnL}+\beta_{2} \operatorname{lnEQ}+\beta_{3} \mathrm{DFE} 1+\beta_{4} \mathrm{DFE} 2+\beta_{5} \mathrm{DFE} 3
$$

Here, VA represents value added, $\alpha$ indicates the constant element, $\mathrm{L}$ is number of employees, $\mathrm{EQ}$ denotes equity and, DFE1, DFE2 and DFE3 are dummies for FEs1, FEs2 and FEs3 respectively. The productivity level of DEs is expressed by the constant element $\alpha$, and those of each foreign firm are represented by the sum of $\alpha$ and the corresponding coefficients of dummies. $\beta_{1}$ and $\beta_{2}$ indicate the degree of scale for the whole economy by years. This equation is estimated for each year.

Figures in Table 1 are the estimation results for model (1). They suggest that constant returns to scale prevailed in the economy during the four-year period, since $\left(\beta_{1}+\beta_{2}\right)$ was 1.08 in $1994,0.99$ in 1995 as well as in 1996, and 1.04 in 1997. (6) Thus, the Cobb-Douglas production function with constant returns to scale can be justified as a proper model for the aggregate production in the Hungarian economy. Coefficients of the dummies for foreign firms show that they have substantially higher TFP. Among them, FEs2 and FEs1 amounted to the highest values in 1994, which were taken by FEs3 and FEs2 in the following two years. Fit of the model is proven by the values of both $\mathrm{F}$ statistic and $\mathrm{R}$ squared.

Table $1 \quad$ Estimation results for equation (1)

\begin{tabular}{|l|c|c|c|c|}
\hline Variables (Coefficients) & 1994 & 1995 & 1996 & 1997 \\
\hline Employee $\left(\beta_{1}\right)$ & $0.740^{\star}$ & $0.587^{\star}$ & $0.601^{\star}$ & $0.665^{\star}$ \\
& $(6.67)^{1}$ & $(9.48)$ & $(8.75)$ & $(9.61)$ \\
Equity $\left(\beta_{2}\right)$ & $0.336^{\star}$ & $0.406^{\star}$ & $0.393^{\star}$ & $0.371^{\star}$ \\
& $(3.57)$ & $(8.64)$ & $(6.82)$ & $(6.68)$ \\
Constant $(\alpha)$ & $-1.230^{\star \star}$ & -0.172 & -0.142 & -0.416 \\
& $(-2.53)$ & $(-0.59)$ & $(-0.51)$ & $(-1.32)$ \\
Dummy for FEs1 $\left(\beta_{3}\right)$ & $0.554^{\star \star}$ & 0.201 & 0.206 & $0.469^{\star \star}$ \\
& $(2.10)$ & $(1.17)$ & $(1.29)$ & $(2.59)$ \\
Dummy for FEs2 $\left(\beta_{4}\right)$ & $0.557^{\star \star}$ & $0.399^{\star \star}$ & $0.497^{\star}$ & $0.542^{\star}$ \\
& $(2.28)$ & $(2.53)$ & $(3.27)$ & $(3.19)$ \\
Dummy for FEs3 $\left(\beta_{5}\right)$ & $0.488^{\star \star}$ & $0.367^{\star \star}$ & $0.525^{\star}$ & $0.598^{\star}$ \\
& $(2.04)$ & $(2.49)$ & $(3.69)$ & $(3.89)$ \\
\hline R squared adjusted & 0.915 & 0.967 & 0.967 & 0.961 \\
F statistic & 178.05 & 523.87 & 525.70 & 432.23 \\
Number of observations & 89 & 91 & 89 & 91 \\
\hline
\end{tabular}

Notes: I Figures in parentheses are t statistics.

* Significant at $1 \%$ level (two-tailed test).

** Significant at $5 \%$ level (two-tailed test).

Source : See section 3. 
The following model is the basic regression equation of the Cobb-Douglas production function, estimated for four categories of firms with 1997 data.

$\ln \mathrm{VA}=\alpha+\beta_{1} \ln \mathrm{L}+\beta_{2} \ln \mathrm{EQ}$

The most important finding that emerges from the examination of Table 2 is the increasing returns to scale at FEs3. On the contrary, FEs1 show decreasing returns to scale, while DEs seem to have rather constant scale. The $t$ statistics of $\left(\beta_{1}+\beta_{2}\right)$ for FEs3 and FEs1 also prove at a 5\% significance level that their returns to scale is different from unity. Due to the difference in the returns to scale, we cannot interpret the lower constant terms as indications of lower efficiency.

It may be claimed that there exists the problem of multicollinearity between equity and labor in both models above, but its possibility is low due to that the analysis was cross-section. In addition, the values of the correlation coefficients between equity and labor extend only from 0.48 to 0.81 .

Table 2 Estimation results for equation (2)

\begin{tabular}{|l|c|c|c|c|}
\hline Variables (Coefficients) & DEs & FEs1 & FEs2 & FEs3 \\
\hline Employee $\left(\beta_{1}\right)$ & $0.699^{\star}$ & $0.608^{\star}$ & $0.511^{\star}$ & $0.560^{\star}$ \\
& $(11.39)^{1}$ & $(5.05)$ & $(3.24)$ & $(3.16)$ \\
Equity $\left(\beta_{2}\right)$ & $0.312^{\star}$ & $0.239^{\star \star}$ & $0.537^{\star}$ & $0.552^{\star}$ \\
& $(5.54)$ & $(2.87)$ & $(4.43)$ & $(3.60)$ \\
Constant $(\alpha)$ & -0.126 & $1.463^{\star}$ & -0.171 & -0.764 \\
& $(-0.45)$ & $(3.29)$ & $(-0.41)$ & $(-1.46)$ \\
\hline R squared adjusted & 0.984 & 0.908 & 0.957 & 0.951 \\
F statistic & 727.75 & 99.88 & 243.95 & 216.36 \\
Number of observations & 24 & 21 & 23 & 23 \\
\hline
\end{tabular}

Notes : 1 Figures in parentheses are $t$ statistics.

* Significant at $1 \%$ level (two-tailed test).

$* *$ Significant at $5 \%$ level (two-tailed test).

Source : See section 3

\section{Spillover impact of foreign firms}

The model here is based on that foreign investment, through externalities, raise the efficiency at domestic firms if there is a positive relation between the labor productivity of domestic firms and the labor share of foreign firms in an industry. (7) Due to the constraints of the lack of data, we cannot use the total factor productivity indicator, and are not able to control for many of the factors influencing the value added per labor ratio. We can only control for the capital intensity of domestic firms, measured by its proxy of equity per labor. ${ }^{(8)}$

The logic behind the model is the same as that at Blomstrom and Persson (1983). We estimate the spillover effect by using figures of sectors of the same years of the period 1994-1997 for the dependent as well as independent variables. The model attempts to shed some light on how the size of foreign share affects the labor productivity of domestic firms in sectors.

$$
\operatorname{lnVLd}=\alpha+\beta_{1} \ln E L d+\beta_{2} \mathrm{FLS}+\beta_{3} \mathrm{FLS}^{2}
$$

Here VLd represents value added divided by the total number of employees at domestic firms, $\alpha$ indicates the constant element, ELd denotes equity per total number of employees at domestic firms, FLS is the share of employees employed at foreign firms in an industry. FLS2 is used to improve the appropriateness of the model if the relationship is not linear between the dependent and independent variables. 
Table 3 Estimation results for equation (3)

\begin{tabular}{|lc|}
\hline Variables (Coefficients) & \\
\hline Constant $(\alpha)$ & $-0.509^{\star}$ \\
Equity/ employees $\left(\beta_{1}\right)$ & $(-10.56)^{1}$ \\
& $0.294^{\star}$ \\
Labor share of foreign firms $\left(\beta_{2}\right)$ & $(10.60)$ \\
& $0.712^{\star \star}$ \\
Labor share of foreign firms, squared $\left(\beta_{3}\right)$ & $(2.37)$ \\
& $-0.990^{\star}$ \\
\hline R squared & $(-2.62)$ \\
F statistic & 0.58 \\
Number of observations & 41.71 \\
\hline
\end{tabular}

Notes: I Figures in parentheses are $t$ statistics

* Significant at $1 \%$ level (two-tailed test).

**Significant at $5 \%$ level (two-tailed test).

Source : See section 3 .

The method of estimation is the ordinary least squares at both models, and the results obtained are shown in Table 3. As the coefficient and t-value of the variable of foreign labor share show, we cannot reject the hypothesis that a positive spillover effect exists. The impact seems to be strong in the hotel and restaurant, the transport and furniture industries or sales, where the labor shares of foreign firms are between $20 \%$ and $32 \%$. On the other hand, the negative coefficient for the squared labor share shows that this effect disappears if foreign firms become dominant, like in the chemical industry, non-metal products, and mail and communication (60\%-86\%). The scope of data did not allow estimating the spillover impacts in separate industries or by firm scale. In comparison with the results of the study of Blomstrom and Persson (1983) for Mexico, we find a weaker support for the spillover efficiency hypothesis, partly because we have much fewer factors to control for in the model, partly because the squared expression for the foreign participation in industries is negative.

\section{Conclusion}

This paper has analyzed the total factor productivity of domestic enterprises and three groups of foreign firms, and estimated the spillover effect from the foreign capital in the Hungarian economy in 1994-1997. In line with the theoretical considerations, foreign firms are found to have more efficient production methods. FEs3 and FEs2 seem to account for greatest efficiency and indicate increasing returns to scale. The empirical evidence shows that some kind of positive spillover impact from the presence of foreign capital exists in the economy of Hungary. However, the results in our regression model indicate that this effect is visible only if the foreign participation in industries is not so dominant. In turn, as the share of foreign firms, mainly due to privatization, becomes extremely important in an industry, the productivity of domestic firms seems to decline considerably, which may be caused by a substantial drop in the number of those with good performance.

\section{Notes}

Thanks are given to Professor Yuzo Hosoya for his valuable assistance in conducting the econometric 
analysis. Helpful suggestions on earlier version of the paper from Professor Masao Satake, Professor Kazuo Yokokawa and Associate Professor Ichiro Daito are gratefully acknowledged. I am also indebted to Professor Toshiyuki Kagawa and Professor Haruki Niwa for their comments, on the 1999 congress of The Japanese Association for Russian and East European Studies.

(1) Dunning (1993), pp. 80-81.

(2) For a survey see Caves (1996), pp.226-227.

(3) Dunning (1993), pp. 455-463.

(4) Dunning (1993), pp. 465-469.

(5) Problems of TFP measurement are surveyed and discussed by Nishimizu and Robinson (1984).

(6) This is also confirmed by the t statistics of $\left(\beta_{1}+\beta_{2}\right)$, which show that the difference of $\left(\beta_{1}+\beta_{2}\right)$ from 1 is not significant.

(7) As an alternative measure for foreign participation, the variable of foreign sales share in each industry was also constructed, but the employment measure gave much higher t-values and somewhat higher $R$ squared values in the models.

(8) The measure of capital intensity is affected by the number of shifts worked, but since we are not provided with any information on such matter, we must assume that its rate is similar across industries.

\section{References}

* Agarwal, J. P. (1979), 'Productivity of Foreign and Domestic Firms in Indian Industries', Weltwirtschaftliches Archiv, 115, pp. 116-127.

* Blomstrom, M. and H. Persson (1983), 'Foreign Investment and Spillover Efficiency in an Underdeveloped Economy: Evidence from the Mexican Manufacturing Industry', World Development, 11, pp. 493-501.

* Caves, R. E. (1996), Multinational Enterprise and Economic Analysis, Cambridge University Press.

* Dunning, J. H. (1993), Multinational Enterprises and the Global Economy, Reading: Addison-Wesley.

* Hunya, G. (1997), 'Large Privatization, Restructuring and Foreign Direct Investment', WIIW ReprintSeries, March, No. 166, Vienna.

* Nishimizu, M. and S. Robinson (1984), 'Trade Policies and Productivity Change in Semi-Industrialized

Countries', Journal of Development Economics 16, pp. 177-206.

* Romer, D. (1996), Advanced Macroeconomics, McGraw-Hill.

* Sterner, T. (1990), 'Ownership, Technology, and Efficiency: An Empirical Study of Cooperatives, Multinationals, and Domestic Enterprises in the Mexican Cement Industry', Journal of Comparative Economics, 14, pp. 286-300.

* Sun, H. (1998), Foreign Investment and Economic Development in China: 1979-96, Ashgate.

* Terrell, K. (1992), 'Productivity of Western and Domestic Capital in Polish Industry', Journal of Comparative Economics, 16, pp. 494-514.

* Tyler, W. G. (1978), 'Technical Efficiency and Ownership Characteristics of Manufacturing Firms in a Developing Country: A Brazilian Case Study', Weltwirtschaftliches Archiv, 114, pp. 360-379. 


\section{SUMMARY}

The foreign share in nominal capital in the economy of Hungary reached 35\% by 1997, which points to the important role of foreign enterprises. Eclectic theory of Dunning suggests that firms operating in more than one country have specific competencies, which are not available to purely national firms. It may be reasonable to expect that these advantages are reflected in relatively higher productivity. It is also assumable that foreign firms as the possessors of international production experience positively affect the economic performance of domestic enterprises through external, the so-called spillover effects. One type of these effects may take the form of linkages with suppliers of foreign firms, such as information linkages or technical assistance, while other widely acknowledged impact is that through increasing competition in the industry they operate, which inspires rival domestic firms to better performance.

To estimate the productivity of foreign firms relative to that of domestic companies in Hungary, total factor productivity is calculated for the aggregate balance sheet data of all enterprises that were obliged to report to the Tax and Financial Audit Office in the period between 1994 and 1997. Three types of foreign firms are distinguished according to the size of foreign share in nominal capital. Spillover impact is also calculated to see whether the presence of foreign firms in an industry contributes to the increase in the labor productivity of domestic companies.

The most important finding that emerges from the examination is the more efficient production methods of foreign firms, among which those with foreign share more than $25 \%$ seem to account for the greatest efficiency. Majority foreign-owned firms have increasing returns to scale, while domestic enterprises show rather constant scale. The empirical evidence shows some kind of positive spillover impact, but this effect is visible only if the foreign participation in industries is not so dominant.

Key words : transition economies

foreign firms

total factor productivity

spillover effect 